\title{
ATTITUDES TOWARD FARM ANIMALS WELFARE AND CONSUMER'S BUYING INTENTIONS - CASE OF SERBIA
}

\author{
Saša Veljkovićc ${ }^{1}$, Žaklina Stojanović2 ${ }^{2}$ Jelena Filipovićc ${ }^{3}$
}

\begin{abstract}
Summary
The aim of this study is to examine consumers' perception of the products considering animal welfare and to establish the factors which affect consumers 'willingness to pay the premium price for the animal-friendly products. In addition, four consumers 'profiles according to their attitudes towards farm animals'welfare are distinguished and their features are elaborated. The research has been undertaken in Belgrade, comprising 198 participants. The face-to-face interview technique has been adopted, while for the analysis of the results regression and cluster analyses have been performed. The findings suggest that food sector stakeholders should put more efforts in providing information and education to the consumers regarding the importance of animal welfare and that there is a significant market potential for the introduction of the label for animal-friendly products. The implications for policy makers are proposed and discussed too.
\end{abstract}

Key words: animal welfare, consumers, market segmentation, food, Serbia.

JEL: $131, M 31, Q 13$

\section{Introduction}

Food labelling addresses a set of issues on consumer information. The innovative animal welfare labelling and consumer attitudes toward farm animals' welfare are in the focus of our research. Animal welfare (AW) is strongly linked to agricultural practices. Due to population growth, agricultural producers all over the world have been constantly forced to increase supply. Consequently, agribusiness sector stakeholders have been obliged to apply innovative and highly productive methods commonly marked as

1 Saša Veljković, Ph.D., Associate professor, Faculty of Economics, University of Belgrade, Kamenička Street no. 6, 11000 Belgrade, Serbia, Phone: +381 1130211 25, E-mail: veljkos@ekof.bg.ac.rs

2 Žaklina Stojanović, Ph.D., Full professor, Faculty of Economics, University of Belgrade, Kamenička Street no. 6, 11000 Belgrade, Serbia, Phone: +381 1130211 62, E-mail: zaklina@ekof.bg.ac.rs

3 Jelena Filipović, Ph.D., Assistant professor, Faculty of Economics, University of Belgrade, Kamenička Street no. 6, 11000 Belgrade, Phone: +381 1130210 23, E-mail: jilipovic@ekof.bg.ac.rs

EP 2015 (62) 1 (53-71) 
the Green revolution package. However, the Revolution led to the numerous hazards related to land use, quality of environment and human health (Zakić, Stojanović, 2008).

Starting from 1990s the set of agricultural policy measures has been designed to redirect overall public support from the pure efficiency approach toward production of high value added food. AW is usually treated as the societal and consumer concern. From the social point of view, specific AW food labels appeal to a wider public, and include specific ethics considerations. On the other hand, consumers are particularly concerned about the way animals have been treated on the farm. However, the conducted studies failed to explain why consumers in general are not empowered to respond to higher AW standards. Previously mentioned facts indisputably approve the importance of the research related to the explanation of consumers' attitudes toward AW. It is also important to notice that the AW market is emerging regardless of the geographical scope, and research in both developed and developing countries are of particular interest to wider public (namely, consumers, food companies, retailers, food sector stakeholders in general, and public policy makers). They are highly interested in the specific results and recommendations obtained from the innovative AW research.

As far as Serbia is concerned, the AW issues can be observed strictly from the normative point of view. The Food Safety Law was adopted in 2009 (Official Gazette, no. 41/2009). The law provisions provided the overall framework for the legislative related to food labelling in general, including AW issues. Under the accession and related harmonization processes, the Law on Animal Welfare was adopted by Serbian parliament simultaneously with the Food Safety Law (Official Gazette, no. 41/2009). However, the legislative simply push producers to improve their technology without any attention paid to consumer awareness and attitudes toward specific AW issues. The main objective of this paper is to elaborate the first findings related to connections between consumers' attitudes toward AW and buying intentions in our country. The main research questions are defined as follows: (RQ1) Do respondents have positive attitudes to AW concept in general?; (RQ2) Which variables best explain the respondents' willingness to pay a premium price for AW products?; (RQ3) Who are the early adopters at the market - or which clusters according to the consumer's intended behaviour towards AW products can be identified at the emerging Serbian market?

\section{Theoretical background and literature review}

In the last two decades the topic of consumers' food choice has drawn a lot of attention, both by the scholars and by the practitioners. Given the multidimensional nature of the subject, research has focused on manifold aspects which determine consumers' food selection, such as: food attributes (e.g., healthiness, appearance, nutritional values), consumers' characteristics (demographic, economic, social, psychological, etc.), features of the point of food purchase (e.g., availability, package), etc. The most recent research matters that have been investigated in this sphere are ethical concerns widely recognized as highly influential group of determinants of consumers' purchase behaviour (Steptoe et al., 1995). However, the consumer concerns about AW and the 
impact on food choice have been distinguished by the scholars quite recently, and therefore, they yet need to be studied more thoroughly.

Given that the introduction of the higher AW standards will induce the increase in costs of the supply-chain participants, it is very important to establish whether consumers are willing to pay more for certified animal-friendly products. Previous studies conducted on this matter revealed ambiguous findings. For example, Nocella and associates (2010) determined a positive relationship between consumers' willingness to pay and animalsfriendly certification, while Theuvsen and associates (2006) failed to prove the same. More precisely, it is concluded by several studies (e.g., Napolitano et al., 2008; European Commission, 2009) that consumers claim to be willing to pay more for the food produced in accordance with farm AW, however, they do not translate that intention into practice at the point of purchase. Some studies (e.g., Harper, Henson, 2001) acknowledged that consumers did not perceive AW to be directly correlated with their health or convenience, and thus it was not a priority for them when making a purchase.

Nevertheless, several factors demonstrated to be significant for the extent of the consumers' willingness to pay for animal-friendly products. In line with the attributes that affect consumers' purchase decisions of specific food categories, such as: functional food (e.g. Filipovic, Stojanovic, 2013), organic food (e.g. Shih Jui et al., 2015) or fair-trade products (e.g. Pelsmacker et al., 2006), the body of subject literature indicates that they also determine the willingness to pay for products labelled with AW. The most prominent variations determinants are established to be socio-demographic factors. Previous research (Lagerkvist, Hess, 2011, Kehlbacher et al., 2012; Grimsrud et al., 2013) consistently acknowledged that age, income, gender and the level of education played significant role in the distinguishment of consumers' willingness to pay for animal-friendly products. In addition, the presence of children in the household (Toma et al., 2012), as well as whether family owed a pet (Harper, Henson, 2001), influenced how prone they would be to pay premium price for products which considered animal welfare.

Besides socio-demographic characteristics, consumers' willingness to pay for the subject products is determined by their knowledge and beliefs. As proposed by Boogaarda and associates (2006), consumption of animal products should be observed from the perspective of values, convictions, emotional experiences (with animals and farms) and factual knowledge on farm animals' treatment. In addition, it is also claimed that self-rated knowledge and level of concern for AW influenced consumers' willingness to pay (Taylor, Signal, 2009). However, the findings on the relations of consumers' willingness to pay and their knowledge and beliefs are rather equivocal; given that consumers' level of informativeness and extent of their concern for AW do not always change in opposite directions (Belegu et al., 2014). In fact, individuals can hold two views on AW. On the one hand, as the society members, they may support the notion of animals being entitled to a good life, but as consumers, they can avoid the cognitive connection with the live animal (Schröder, McEachern, 2004). 
Taking all of these into considerations, this research aims to ascertain the features which influence consumers' willingness to pay for animal-friendly products; and to indicate consumers' segments, with respect to these products, in Serbia. Previous research (Ingenbleek et al., 2013) showed great disparities between European countries with regard to animal-friendly products, noticing that the European market is still largely fragmented and those different national markets, due to their peculiarities, should to be investigated on this matter. This study helps the global discussion on the consumers' perception and behaviour related to farm AW and represents one of the first studies in this domain in Serbia.

Based on all mentioned above, the research model is designed as follows (Figure 1).

Figure1. Proposed research model

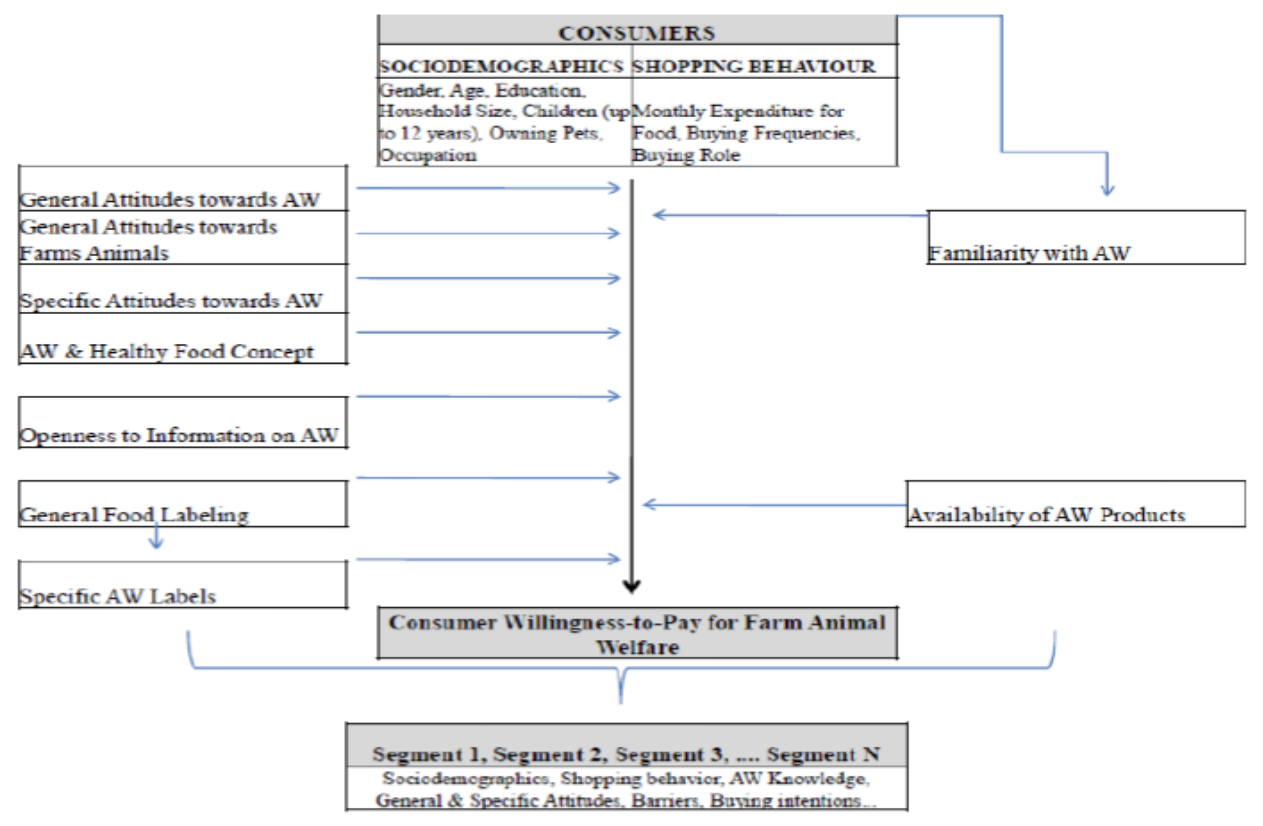

Source: Authors' model based on the literature review and previous research.

\section{The research methodology and data}

In the analysis conducted by Redmond and Griffith (2003), it was established that the method of interviews was the most widely used one for the investigation of the matters related to the consumers' food safety. Authors used face-to-face interviews in their studies in order to explore attitudes, preferences on purchasing intentions and consumer behaviour in the field of animal-friendly products (Vecchio, Annunziata, 2012; Toma et al., 2011).

Our survey of consumer attitudes of the impact of farm animals' welfare on food quality and safety was conducted in April 2014, in Belgrade. The survey included 198 respondents, aged 18 and above, both males and females (Stojanović et al., 2014a). A method of interception interview in front of previously mapped retail stores was implemented. Different retail 
formats were included, ranging from the mini-markets to the large supermarkets in the shopping malls. A structured questionnaire was used to collect data on the level of awareness and knowledge of the respondents, and their attitudes towards the welfare of farm animals and animal-friendly products.

Assessment of the knowledge. Knowledge scale was used in measuring knowledge about AW practice. There were 5 multiple answers related to this issue. For each correct answer a score of one point was given, and a score of zero point for incorrect answer. A cut off point for low knowledge was 2.5 score and a score of 2.51 points or more was given for higher knowledge. Questions were related to the practical aspects of farm animals breading and the legislative in the field of research in Serbia (Stojanović et al., 2014b). Respondents, regardless of the conducted test, had the opportunity to provide a self-assessment of their knowledge of farm animal treatment.

Measurement of attitudes. Respondents were asked to provide a self-report on their attitudes towards AW. Attitudes were examined using a seven-point Likert scale. The most of the statements are defined taking into account the previously conducted research in this area (Vecchio, Annunziata, 2012; Matsuoka, Sorenson, 2013). Respondents were requested to indicate general and specific attitudes towards the welfare of animals, as well as the attitudes associated with AW labelling, the availability of such products and willingness to buy them.

Socio-demographic and buying behaviour characteristics. The general socio-demographic characteristics of the respondents were collected at the end of the interview. They are referred to the usual data such as: gender, age, level of education, household size, occupation, number of children, household income, owning pets, etc. Data on the characteristics regarding purchasing behaviour were related to: the monthly expenditure for food, buying frequencies of a specific food, and personal role in purchasing of food (major buyer in the family or not).

All questionnaires were checked for completeness and validated. Data analysis was conducted using SPSS software version 20.

Analysis is performed in several phases. Firstly, the basic descriptive statistical analysis and correlations are displayed and calculated. These basic statistical analyses are used to provide indications of the degree of association between two or more factors. In the second phase, linear regression analysis is performed, aiming to determine which factors dominantly influence respondents' willingness to pay higher prices for animal-friendly products. Extracted variables based on the regression analysis, were used as the baseline to distinguish segments with Ward's method of Hierarchical cluster analysis. In the last phase of the analysis, the segments are profiled using ANOVA statistics for analysis of variance comparison of means, and bivariate analysis including cross-tabulation with $\chi 2$ (Chi-squared) statistics and independent samples t-test. Statistical significance is assessed using $\mathrm{p}$-values and all results were considered significant at the level of $\mathrm{p}<0.01, \mathrm{p}<0.05$, or $\mathrm{p}<0.1$. 


\section{Research results and discussion}

Sample characteristics and exploratory analysis

In the Table 1 can be observed socio-demographic and other sample characteristics. $62.1 \%$ of the respondents are females; $53.6 \%$ are aged between 31 and 60;53\% completed secondary school, and 30.8\% obtained BSc degree. Households consisting of four members are most frequent (42.4\%) in our sample. Approximately half of the respondents $(51 \%)$ spend monthly between 20,000.00 and 39,999.00 RSD on food. The other sample features that should be noticed are: $45.5 \%$ are pet owners; $43.4 \%$ are major shoppers in the household; $30.3 \%$ are parents of the children under 12 years old; and $75.3 \%$ visited a farm at least once.

Table 1. Sample characteristics

\begin{tabular}{|c|c|c|c|c|c|}
\hline Characteristics & $\begin{array}{l}\text { Sample } \\
(n=198)\end{array}$ & Percent & Characteristics & $\begin{array}{l}\text { Sample } \\
(n=198)\end{array}$ & Percent \\
\hline \multirow{2}{*}{ Gender } & Female & 62.1 & \multirow{7}{*}{$\begin{array}{l}\text { Monthly } \\
\text { Expenditure for } \\
\text { Food }\end{array}$} & $\begin{array}{l}\text { up to } 10.000 \\
\text { RSD }\end{array}$ & 3.5 \\
\hline & Male & 37.9 & & \begin{tabular}{|l|}
10,000 to \\
$19,999 \mathrm{RSD}$
\end{tabular} & 20.2 \\
\hline \multirow{4}{*}{ Age } & $18-30$ & 31.3 & & \begin{tabular}{|l}
20,000 to \\
$29,999 \mathrm{RSD}$
\end{tabular} & 27.3 \\
\hline & $31-45$ & 26.8 & & \begin{tabular}{|l|}
30,000 to \\
$39,999 \mathrm{RSD}$
\end{tabular} & 23.7 \\
\hline & $46-60$ & 26.8 & & $\begin{array}{l}40,000 \text { to } \\
49,999 \text { RSD }\end{array}$ & 17.2 \\
\hline & over 61 & 15.2 & & $\begin{array}{l}\text { over } 50,000 \\
\text { RSD }\end{array}$ & 7.6 \\
\hline \multirow{4}{*}{ Level of Education } & Primary school qualifications & 2.5 & & Missing & 0.5 \\
\hline & Secondary school qualifications & 53 & \multirow{7}{*}{ Household Income } & no income & 1 \\
\hline & $\begin{array}{l}\text { Two-year post-secondary } \\
\text { school qualifications or BA }\end{array}$ & 13.6 & & $\begin{array}{l}\text { up to } 20.000 \\
\text { RSD }\end{array}$ & 1.5 \\
\hline & Bachelors' degree (BSc) & 30.8 & & \begin{tabular}{|l|}
20,000 to \\
39,999 RSD
\end{tabular} & 15.7 \\
\hline \multirow{7}{*}{$\begin{array}{l}\text { Household } \\
\text { Size }\end{array}$} & 1 & 6.1 & & $\begin{array}{l}40,000 \text { to } \\
79,999 \text { RSD }\end{array}$ & 38.9 \\
\hline & 2 & 18.7 & & $\begin{array}{l}80,000 \text { to } \\
119,999 \text { RSD }\end{array}$ & 22.7 \\
\hline & 3 & 19.2 & & $\begin{array}{l}\text { over } 120,000 \\
\text { RSD }\end{array}$ & 12.6 \\
\hline & 4 & 42.4 & & no answer & 7.6 \\
\hline & 5 & 7.6 & \multirow{2}{*}{ Owning Pets } & Yes & 45.5 \\
\hline & 6.00 and over & 4.5 & & No & 54.5 \\
\hline & Missing & 1.5 & \multirow[b]{3}{*}{$\begin{array}{l}\text { Respondent is a } \\
\text { Major Shopper }\end{array}$} & Yes & 43.4 \\
\hline \multirow{4}{*}{$\begin{array}{l}\text { Number of } \\
\text { Children } \\
\text { (up to } 12 \text { years) }\end{array}$} & 0 & 68.2 & & No & 27.8 \\
\hline & 1 & 20.2 & & $\begin{array}{l}\text { Members } \\
\text { participate } \\
\text { equally in the } \\
\text { purchase }\end{array}$ & 28.8 \\
\hline & 2 & 10.1 & \multirow{2}{*}{$\begin{array}{l}\text { Respondent Visited } \\
\text { the Farm }\end{array}$} & Yes & 75.3 \\
\hline & Missing & 1.5 & & No & 24.7 \\
\hline
\end{tabular}

Source: Authors' calculations according to data from Stojanovic et al., 2014c. 
The research is exploratory in its nature. The sample is not statistically representative for the country. It represents only buyers who prefer buying in different retailers formats in the capital (from the shopping centres to the small shops in the neighbour). Additionally, the presence of different categories of respondents allows us to implement appropriate statistical and logical analysis, highlighting the first results and elaboration of findings related to consumer behaviour toward AW products in Serbia. From the theoretical point of view, our research aims to elaborate the main factors influencing the consumers buying intentions regarding AW products, as well as to identify the first predictors for early assessment of the consumer group that is most willing to pay higher premium for AW products in Serbia.

Figure 2. Respondents' attitudes toward animal welfare

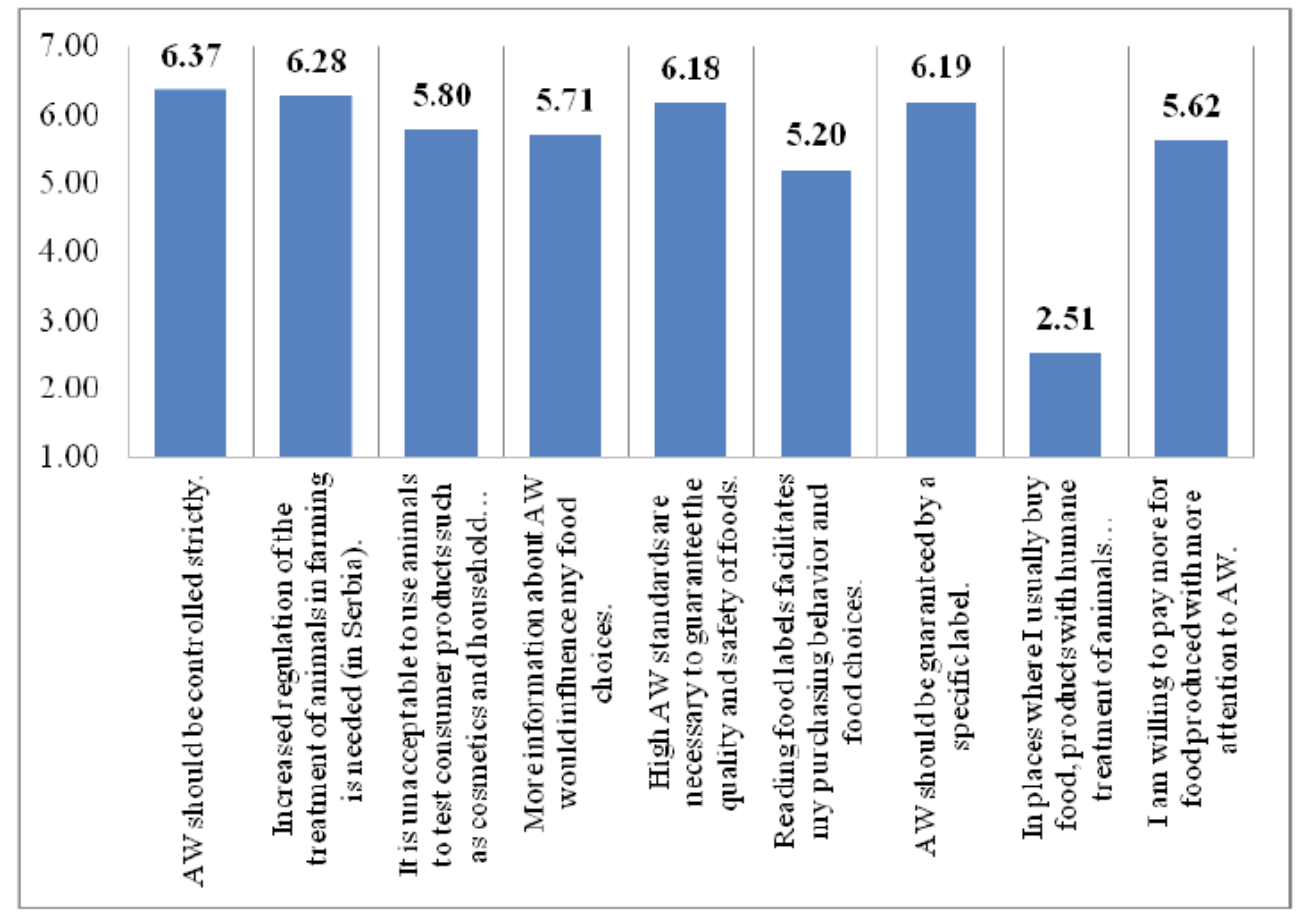

Source: Authors' calculations according to data from Stojanovic et al., 2014c.

The highest level of the agreement respondents express to the claims concerning the control and regulation of AW. On Figure 2 is noticeable that most of the other statements concerning the general and specific aspects of AW and labelling achieved higher agreement scores ( $>5.20$ on 1 to 7 Scale). The claim regarding the availability of the products manufactured in accordance with AW concept is evaluated significantly below average.

Correlation analysis showed a statistically significant correlation $(\mathrm{p}<0.05)$ between the consumers' willingness-to-pay premium price and all presented statements regarding AW (see Table 2). 
Table 2. The correlation between the willingness-to-pay premium price and attitudes regarding AW

\begin{tabular}{|c|c|c|c|c|c|}
\hline \multirow{8}{*}{$\begin{array}{l}\text { I am willing to } \\
\text { pay more for food } \\
\text { produced with more } \\
\text { attention } \\
\text { to AW. }\end{array}$} & Attitudes & $\begin{array}{l}\text { Increased } \\
\text { regulation } \\
\text { of the } \\
\text { treatment } \\
\text { of animals } \\
\text { in farming } \\
\text { is needed } \\
\text { (in Serbia). }\end{array}$ & $\begin{array}{l}\text { AW should be } \\
\text { controlled strictly. }\end{array}$ & $\begin{array}{l}\text { It is unacceptable } \\
\text { to use animals } \\
\text { to test consumer } \\
\text { products such } \\
\text { as cosmetics } \\
\text { and household } \\
\text { detergents. }\end{array}$ & $\begin{array}{l}\text { More information } \\
\text { about AW would } \\
\text { influence my food } \\
\text { choices. }\end{array}$ \\
\hline & $\begin{array}{c}\text { Pearson } \\
\text { Correlation }\end{array}$ & $.367^{* *}$ & $.251^{* *}$ & $.200^{* *}$ & $.435^{* *}$ \\
\hline & $\begin{array}{c}\text { Sig. } \\
\text { (2-tailed) }\end{array}$ & 0 & 0 & 0.005 & 0 \\
\hline & $\mathrm{N}$ & 196 & 196 & 195 & 194 \\
\hline & Attitudes & $\begin{array}{c}\text { AW } \\
\text { should be } \\
\text { guaranteed } \\
\text { by a } \\
\text { specific } \\
\text { label. }\end{array}$ & $\begin{array}{c}\text { High AW } \\
\text { standards are } \\
\text { necessary to } \\
\text { guarantee the } \\
\text { quality and safety } \\
\text { of foods. }\end{array}$ & $\begin{array}{l}\text { In places where I } \\
\text { usually buy food, } \\
\text { products with } \\
\text { humane treatment } \\
\text { of animals' } \\
\text { certificate are } \\
\text { available. }\end{array}$ & $\begin{array}{l}\text { Reading food } \\
\text { labels facilitates } \\
\text { my purchasing } \\
\text { behaviour and } \\
\text { food choices. }\end{array}$ \\
\hline & $\begin{array}{c}\text { Pearson } \\
\text { Correlation }\end{array}$ & $.481^{* *}$ & $.491^{* *}$ & $.146^{*}$ & $.224^{* *}$ \\
\hline & $\begin{array}{c}\text { Sig. } \\
\text { (2-tailed) }\end{array}$ & 0 & 0 & 0.042 & 0.002 \\
\hline & $\mathrm{N}$ & 196 & 196 & 196 & 194 \\
\hline
\end{tabular}

Source: Authors' calculations according to data from Stojanovic et al., 2014c.

In our analysis we observe two groups of respondents regarding their role in family purchase - consumers stating to be the main buyers of food in the household and other. For the most of the statements regarding AW T-test shows statistically significant differences depending on the role of the respondents when buying food:

- AW should be controlled strictly $(\mathrm{p}<0.05)$;

- It is unacceptable to use animals to test consumer products such as cosmetics and household detergents $(\mathrm{p}<0.1)$;

- More information about AW would influence my food choices $(\mathrm{p}<0.05)$;

- Reading food labels facilitates my purchasing behavior and food choices $(\mathrm{p}<0.01)$;

- AW should be guaranteed by a specific label $(\mathrm{p}<0.1)$;

- I am willing to pay more for food produced with more attention to AW ( $p<0.01)$.

The research goal was also to find out whether respondents differ in terms of attitudes towards AW depending on their knowledge regarding the animal friendly practices and products. Respondents were asked to provide self-assessment of knowledge regarding AW. Most of the respondents stated that they were not adequately informed about how animals were treated on the farm $(85.3 \%)$. If we consider the subjectively assessed knowledge 
(respondents who stated that they sufficiently know about AW vs. those who reported not to know about AW at all), a t test failed to reveal a statistically reliable differences $(\mathrm{p}>0.1)$. In addition, we tested the respondents' objective knowledge of AW and legislation in the field of research. The questions referred to the methods of animal breading and their impact on the health of animals and humans. Additional two questions were related to the Law on Food Safety and Animal Welfare Act in Serbia. Results of testing knowledge in the field of AW are given in the Figure 3.

Figure 3. Demonstrated knowledge about the treatment of farm animals (share based on the number of correct answers)

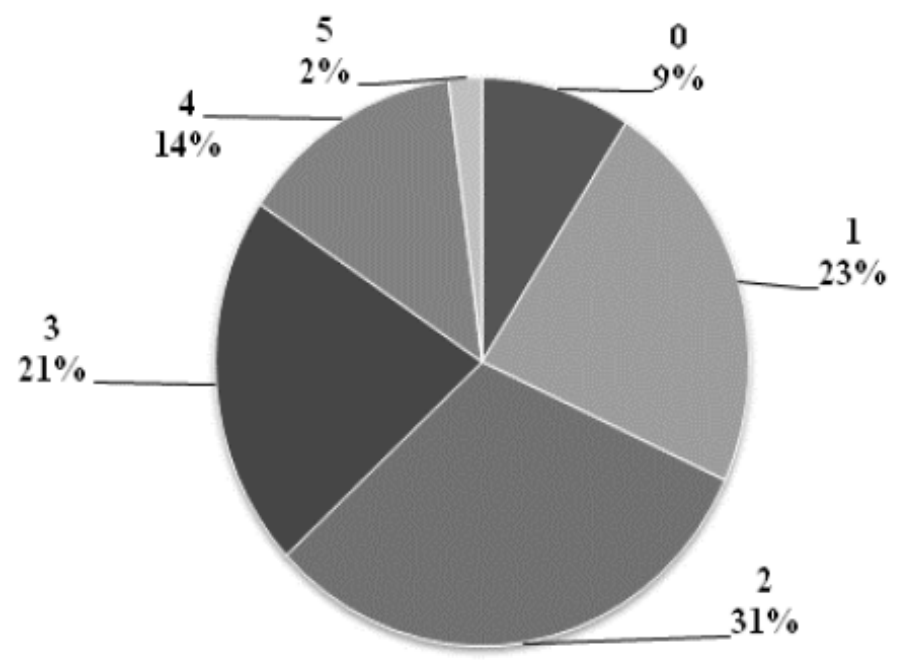

Source: Authors' calculations according to data from Stojanovic et al., 2014c.

Demonstrated knowledge about the treatment of farm animals was very poor. Only $2 \%$ of respondents answered correctly to all five questions. Another 14\% of them provided correct answers to four questions. Majority (54\%) of the respondents answered correctly only to one or two questions regarding the treatment of animals and legislation.

If we observe statistically significant differences between respondents who showed better objective knowledge (answered correctly to more than a half of the questions) compared to those who knew less (answered correctly to one or two questions), $t$ test confirmed the statistically significant difference for two AW claims:

- Reading food labels facilitates my purchasing behaviour and food choices $(\mathrm{p}<0.1)$;

- In places where I usually buy food, products with humane treatment of animals certificate are available $(\mathrm{p}<0.05)$. 
AW and Purchasing behaviour

A multiple regression analysis is performed in order to assess the purchase intentions (Consumer Willingness-to-Pay for Farm AW) relative to eight explanatory variables (consumers' general attitudes towards AW; consumers' general attitudes towards the welfare of farms animals; consumers' specific attitudes towards $A W$; openness to the information on $A W ; A W$ as a guarantee of healthy food; influence of food labels on consumers 'purchasing behaviour; consumers' attitudes towards the AW labels; availability of the $A W$ products). The used predictors have been widely employed in the body of the subject research and proved their explanatory capacity. However, Serbian market of the AW products is emerging, and therefore, the AW products availability is included in our analysis as the additional predictor of consumer behaviour.

In the structural element of the model, the regression parameters explaining purchase intentions indicate that four variables have a significant influence on the dependent variable: attitudes of consumers towards $A W$ labels, $A W$ as a guarantee of healthy food, openness to information on $A W$, and availability of $A W$ products. This multiple regression accounted for $37.4 \%$ of the variability, as indexed by the adjusted $\mathrm{R}^{2}$ statistic $(38.7 \%$ indexed by the $\mathrm{R}^{2}$ statistic).

The regression equation for predicting Consumer Willingness-to-Pay for Farm $A W$ is:

$$
y=0.375 x_{1}+0.306 x_{2}+0.229 x_{3}+0.115 x_{4}-0.182
$$

Where:

$\mathrm{x}_{1}$ - attitudes of consumers towards the AW labels

$\mathrm{x}_{2}-A W$ as a guarantee of healthy food

$\mathrm{x}_{3}$ - openness to information on $A W$

$\mathrm{x}_{4}$ - availability of $A W$ products

The variable Attitudes of consumers towards the AW labels, as indexed by its $\beta$ value of 0.375 , shows the strongest relationship to Consumer Willingness-to-Pay for Farm AW. Consumers' decisions are highly influenced by labels made on foods. However, other three drivers have recorded significant positive effect on AW products purchase intentions in our sample.

Consumers'general attitudes towards the AW, consumers'general attitudes towards the welfare of farmed animals, consumers'specific attitudes towards the $A W$, and general attitudes toward food labels are not revealed to be the significant factors of influence in determination of consumers buying intentions. When it comes to the health as the main reason for purchase of AW products, our respondents simply observe the products characteristics and high added value only in the context of health self-assessment. If the relationship between personal health status (or health status of the family) and products produced using the animal friendly practices is visible, than consumers express more openness to the AW products. Openness also includes the willingness to obtain new information regarding the 
AW products and practices. Finally, willingness to pay premium prices for AW products depends on products availability on the market.

\section{Cluster analysis}

Our research is oriented toward explanation of main differences between identified consumers groups. Cluster analysis allows deeper insight in consumer willingness to pay for AW products. Furthermore, it facilitates set of conclusions relevant both food industry and policy makers in Serbia.

A segmentation of the sample is conducted to verify the existence of homogeneous groups of the respondents in terms of attitudes to AW and willingness to pay for it. For this purpose, cluster analysis is applied as a common technique used in similar studies (Vecchio, Annunziata, 2012; Krystallis et al., 2012). Hierarchical Cluster Analysis (Ward's Method) is performed to obtain segments. The variables used to divide the sample into clusters were: attitudes of consumers towards the AW labels, AW as a guarantee of healthy food, openness to information on AW, and availability of AW products. These variables were selected as key predictors in the regression model. Consequently, the fifth input value for the cluster analysis was the dependent variable of the regression model (Consumer Willingness-to-Pay for Farm AW). The division into four groups was optimal, given the sample size, homogeneity within segments, and heterogeneity between segments. Detailed characteristics of clusters can be observed in Annex.

Cluster 1: Indifferent. The first group of consumers forms $35 \%$ of the sample. Comparing with other identified consumer groups, indifferent don't take care about AW claims, or at least, they are not interested in it. They express more positive attitudes toward AW concerning socially accepted norms. However, indifferent consumers are not generally willing to pay higher prices for AW product. Only Cluster 4 exhibits lower willingness to pay for selected food than Cluster 1. Concerning socio-demographics, males are overrepresented in the group. Household size of this cluster is the largest in the sample, and consequently the monthly expenditures for food are the highest in comparison to other consumer groups. Moreover, this cluster is ranked first by the purchases frequency. Respondents from Cluster 1 are above average in preferring family shopping - family members participate equally in the purchase. Finally, significantly higher share of young and business oriented consumers are noted in this group: $60 \%$ of entrepreneurs, $49 \%$ of students, and $43 \%$ of managers in the sample belong to Cluster 1 .

Cluster 2: Seekers. Cluster 2 (25\% of the sample) is AW oriented in general. This can be seen by the attitudes to AW, and willingness to pay premium prices for AW products. However, in most of the statements, according to the average score, they are lagging behind the third cluster. What makes the members of this segment specific is consumers' knowledge of where they could find and buy AW products. This is the result of their life experience (oldest segment in sample). The cluster consists of the large number of pensioners and unemployed. Their interest in AW is guided primarily by health reasons, or by the fact that they are limited by income. The lack of 'the economic power' is evident in this group. Consequently, although more than half of them are in the role of major buyers in their 
homes, the lowest monthly expenditures for food is recorded in this group comparing to other three clusters in the sample.

Cluster 3: Believers. The Cluster 3 (30\% of the sample) was truly interested in animals and their welfare. Members of this cluster have declared the most positive attitudes toward all claims related to AW. Members of the Cluster 3 highlight the availability of animal-friendly products as the major barrier for higher consumption of the AW products. According to the number and relative participation, females are most represented in this cluster. They keep the role of the "household gate keeper" as they declared to have the main buyer role in their households (major shoppers are nearly 3 out of 5 respondents in this cluster). Almost $40 \%$ of the employed respondents belong to this segment. Believers' spending on the food and the frequency of purchase of chosen product are almost identical to the sample's corresponding means.

Cluster 4: Antagonists. Members of the fourth segment (10\% of the sample) are antagonistic toward the AW. They do not see any reason to pay a premium price for AW products. They are against every specific AW labelling of food. Even when it comes to people's health, they do not perceive any connections between personal health and AW concept. Antagonists are not ready to follow the labels on welfare products. They are even not open to receive any information about AW. The groups of youngest respondents and females are overrepresented in this cluster. In the context of purchase, below average household food expenditures and higher share of persons not involved in the purchase of food in the household are reported in this group.

\section{Conclusions and recommendations}

The main conclusions are presented in the form of the answers to previously defined research questions. The conclusions are derived from the results obtained by the primary research conducted in Belgrade in 2014. Sample size allows us making recommendations based on the capital city consumer behaviour toward AW. The results presented in this study are relevant for the wide group of agricultural sector stakeholders - farmers, food companies, retailers and policy makers in Serbia. The results are also valuable in the context of the theoretical explanation of the main drivers of consumers' willingness to pay premium prices for the AW labelled products.

Regarding the consumers attitudes toward AW concept in general, our research ascertains socially acceptable consumer behaviour. Consumers generally argue about their high awareness towards this issue. From the legislative point of view, they are aware of the fact that AW should be strictly regulated and controlled in the country. Furthermore, they request an increase of the regulation of the animal's treatment at the farm. They simply relay on the state/administrative procedures in the food quality assurance. In the practice, rather low awareness exists. The conclusion is derived by cross-section analysis of specific knowledge and information regarding AW. For example, our respondents are not generally aware of the relations between the AW and personal and public health. They are also poorly informed about AW issues in Serbia. Hence, it is noticeable that respondents' attitudes have been strongly 
influenced both by poor knowledge and information regarding AW, and high pressure of international adjustments of the regulations and laws in the country.

Generally, pure administrative approach to the AW issues is evident. It leads us to the conclusion that Serbia essentially misses demand derived factors that might influence the greater acceptance of the AW products in the practice. The public health policy makers should launch a study to map the current AW education and information activities directed at the general public and consumers in Serbia, which is a prerequisite for further AW products market development. The EU officials also insist on trans-national information campaigns or educational initiatives on AW (European Commission, 2012). However, producers who want to apply the EU standards in the practice will be faced with a change of their production methods which, among others, includes implementation of AW standards as well.

Furthermore, a multiple regression analysis confirms that purchase intentions (Consumer Willingness-to-Pay for Farm AW) are defined by following variables: consumers' attitudes towards the AW labels, the AW concept as a guarantee of healthy food, openness to the information on AW and availability of the AW products. Consumers who are at the moment ready to pay premium price for animal-friendly products are generally guided by the labels made on food and by their perception of the direct correlation among agricultural practices, AW and consumer health. They are open to new information regarding the AW concept and they highly appreciate availability as the significant factor of purchasing intentions. In our study availability is defined as the purchasing convenience (the products I want to buy are available at the place where I regularly shop). The main drivers for better acceptance of AW products at the market are partially derived by the food industry behaviour related to labelling and availability of AW products, and partially by wider public action regarding consumers' information on overall AW importance. From the theoretical point of view, these factors should be more exploited in the further research of consumer willingness to pay for AW products at emerging markets.

When it comes to farmers and food industry interests, they are extremely focused on the results of the early adopters' identification. The most interesting market segment is identified as Believers. They are more social in nature than average, since they believe in generally accepted social norms. They are completely open for new information on products label particularly connected with the personal and family health status, and are the best class of word of label. They are overrepresented by the mothers as the household gate keepers. This segment consists of almost every third respondent in our sample. However, the results should be exclusively interpreted and valid for the food market in the capital city, where the potential for AW products acceptance is the highest in comparison to other regions. The potential consumer group that should be also took into consideration and targeted by the business sector is Indifferent. It consists of consumers dedicated to the new and modern life style. In the transition societies this group of consumers acts slightly different than in the developed countries. Their food habits are dominantly distorted by modern managers, entrepreneurs or younger population way of life. However, they have registered higher expenditures on food consumption in our sample. Changing of the life style should be also facilitated by the 
officials who should take more care about the overall health status of the population.

Finally, the research faced some limitations. First of all, sample size is rather small and not representative nationwide. Second, we are aware of the limitation that the answers of the surveyed respondents regarding AW concept could be "socially desirable" by their nature, and not reflect the real attitude of the respondents. Additionally, the survey was conducted in the period of economic crisis, the stage generally characterized by the decline in consumers' standard of living and consumption. Eventually, buying intention, as the most of previously conducted studies confirmed, have to be converted into actual purchase behaviour. However, despite these limitations, our study gives early evidence on possibilities of AW product market development in Serbia and recommendations for both food chain stakeholders and policy makers responsible for the further AW product market development. 


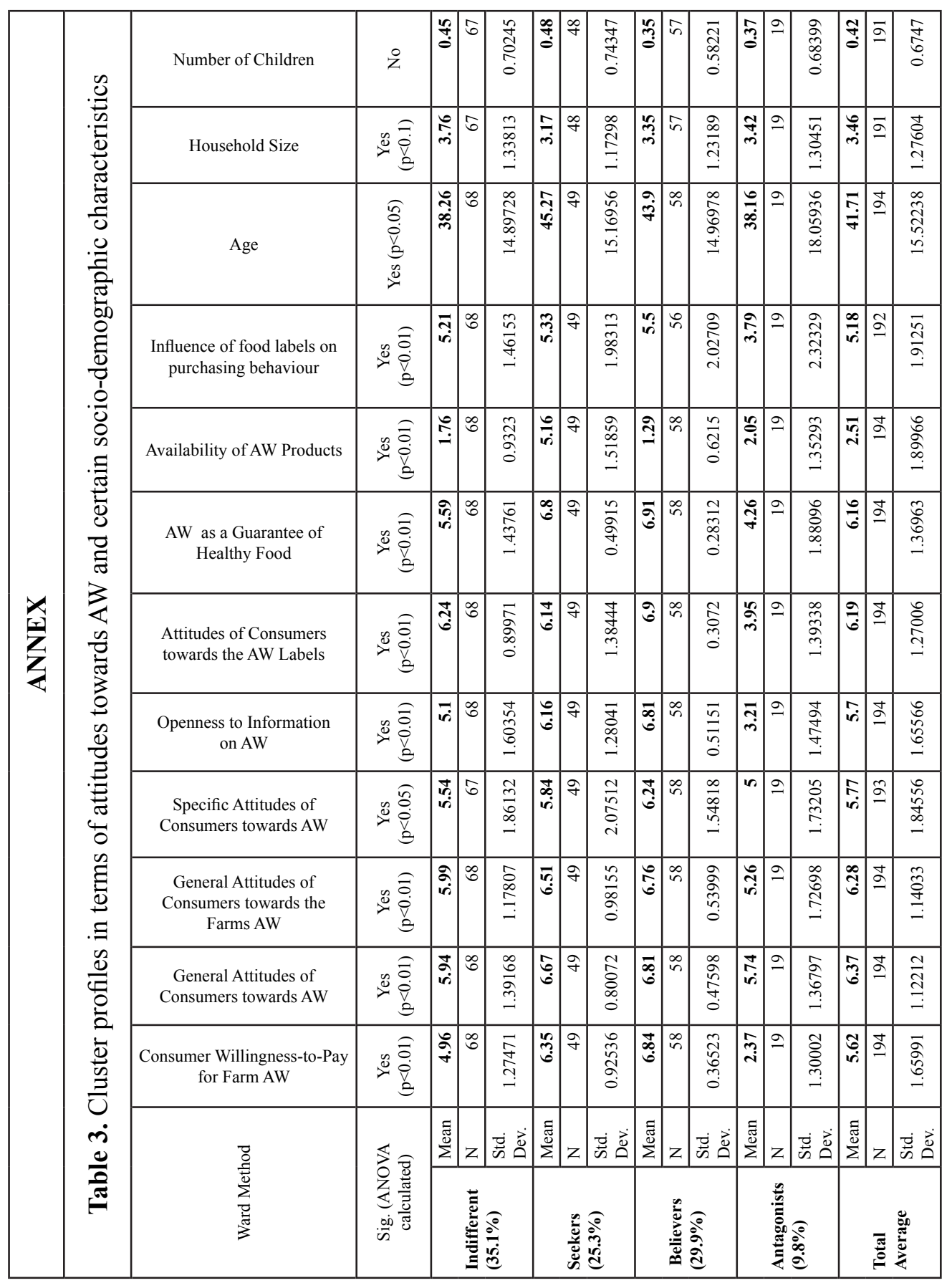

Source: Authors' calculations according to data from Stojanovic et al., 2014c. 
Table 4. Cluster profiles in terms of socio-demographic characteristics and shopping behavior

\begin{tabular}{|c|c|c|c|c|c|}
\hline $\begin{array}{c}\text { Ward } \\
\text { Method }\end{array}$ & Gender & Occupation & $\begin{array}{l}\text { Frequency of } \\
\text { buying Eggs }\end{array}$ & $\begin{array}{l}\text { Monthly } \\
\text { Expenditure } \\
\text { for Food }\end{array}$ & $\begin{array}{l}\text { Whether } \\
\text { respondents are } \\
\text { the main persons } \\
\text { responsible for } \\
\text { buying food? }\end{array}$ \\
\hline $\begin{array}{l}\text { Indifferent } \\
(35.1 \%)\end{array}$ & $\begin{array}{c}\mathrm{M}-50 \%, \mathrm{~F}-50 \% \\
\text { ( } 46 \% \text { of men in } \\
\text { the sample belong } \\
\text { to this cluster) }\end{array}$ & $\begin{array}{l}\text { Although in this segment } \\
\text { is the most workers, it } \\
\text { should be noted that: } 60 \% \\
\text { of entrepreneurs, } 49 \% \\
\text { of students, and } 43 \% \text { of } \\
\text { managers in the sample } \\
\text { belong to segment } 1\end{array}$ & $\begin{array}{c}\text { Most often } \\
\text { buying eggs } \\
\text { (minimum once } \\
\text { a week - 79.4\%) }\end{array}$ & $\begin{array}{l}\text { The biggest } \\
\text { spenders } \\
(60.2 \% \text { over } \\
30.000 \text { RSD } \\
\text { per month) }\end{array}$ & $\begin{array}{c}\text { Members } \\
\text { participate } \\
\text { equally in the } \\
\text { purchase }-38 \%\end{array}$ \\
\hline $\begin{array}{l}\text { Seekers } \\
(25.3 \%)\end{array}$ & $\begin{array}{c}\text { Average gender } \\
\text { distribution (F- } \\
63.3 \%, \mathrm{M}-36.7 \%)\end{array}$ & $\begin{array}{l}35 \% \text { of pensioners, } 31 \% \\
\text { of unemployed, and } 27 \% \\
\text { of workers in the sample } \\
\text { belong to segment } 2\end{array}$ & $\begin{array}{l}\text { Average buyers } \\
\text { (minimum once } \\
\text { a week }-61.3 \% \text { ) }\end{array}$ & $\begin{array}{c}\text { Minimum } \\
\text { spend for } \\
\text { food }(64.6 \% \\
\text { below } \\
30.000 \text { RSD } \\
\text { per month) }\end{array}$ & $\begin{array}{c}\text { Major buyers - } \\
53 \%\end{array}$ \\
\hline $\begin{array}{l}\text { Believers } \\
(29.9 \%)\end{array}$ & $\begin{array}{c}\text { Predominantly } \\
\text { female cluster } \\
\text { (F-72.4\%, M - } \\
27.6 \%)\end{array}$ & $\begin{array}{l}38 \% \text { of workers, and } 32 \% \\
\text { of pensioners in the sample } \\
\text { belong to segment } 3\end{array}$ & $\begin{array}{l}\text { Average buyers } \\
\text { (minimum once } \\
\text { a week }-62.1 \% \text { ) }\end{array}$ & $\begin{array}{c}\text { Average } \\
\text { spending } \\
(50 \% \text { below, } \\
\text { and } 50 \% \\
\text { over } 30.000 \\
\text { RSD } \\
\text { per month) }\end{array}$ & $\begin{array}{c}\text { Major buyers - } \\
57 \%\end{array}$ \\
\hline $\begin{array}{l}\text { Antagonists } \\
(9.8 \%)\end{array}$ & $\begin{array}{c}\text { Above average } \\
\text { female cluster (F- } \\
68.4 \%, \mathrm{M}-31.6 \%)\end{array}$ & $\begin{array}{l}17 \% \text { of students, and } 29 \% \\
\text { of managers in the sample } \\
\text { belong to segment } 4\end{array}$ & $\begin{array}{c}\text { Rarest } \\
\text { buying eggs } \\
\text { (only } 42.1 \% \\
\text { minimum once } \\
\text { a week) }\end{array}$ & $\begin{array}{c}\text { Below } \\
\text { average } \\
\text { spending } \\
(63.2 \% \\
\text { below } \\
30.000 \text { RSD } \\
\text { per month })\end{array}$ & $\begin{array}{l}\text { Not frequently } \\
\text { involved in } \\
\text { buying food for } \\
\text { household - 53\% }\end{array}$ \\
\hline $\begin{array}{l}\text { Total } \\
\text { (Sample) }\end{array}$ & $\begin{array}{c}\text { Female } 61.9 \% \text {, } \\
\text { Male } 38.1 \%\end{array}$ & $\begin{array}{c}\text { Students - } 18 \% \text {, } \\
\text { entrepreneurs - } 8 \% \text {, } \\
\text { workers - } 42 \% \text {, managers } \\
\text { - } 7 \% \text {, unemployed - } 8 \% \text {, } \\
\text { pensioners - } 16 \%\end{array}$ & $\begin{array}{c}\text { Minimum once } \\
\text { a week - } 66 \%\end{array}$ & $\begin{array}{c}\text { Below } \\
30.000 \text { RSD } \\
\text { per }-51.2 \% \text {, } \\
\text { and over } \\
30.000 \text { RSD } \\
\text { per month - } \\
48.8 \%\end{array}$ & $\begin{array}{c}\text { Major buyers } \\
-43 \% \text {; Not } \\
\text { frequently } \\
\text { involved - } 28 \% \text {; } \\
\text { Members } \\
\text { participate } \\
\text { equally - } 29 \%\end{array}$ \\
\hline $\begin{array}{l}\text { Chi-Square } \\
\text { Tests }\end{array}$ & $($ Sig. $\mathrm{p}<0.01)$ & (Sig. $\mathrm{p}<0.1)$ & $($ Sig. $\mathrm{p}<0.05)$ & $($ Sig. $\mathrm{p}<0.01)$ & (Sig. $\mathrm{p}<0.01)$ \\
\hline
\end{tabular}

Source: Authors' calculations according to data from Stojanovic et al., 2014c.

\section{Literature}

1. Belegu, K., Zalla, P., Belegu, M., Laçi, D., Ozuni, E., Andoni, E. (2014): Albanian consumer's perception towards animal welfare, Albanian Journal of Agricultural Sciences, Special edition, pp. 299-303.

2. Boogaarda, B. K., Oostinga, S. J., Bockb, B. B. (2006): Elements of societal perception of farm animal welfare: A quantitative study in The Netherlands, Livestock Science, Vol. 104, No. 1-2, pp. 13-22. 
3. European Commission (2009): Feasibility study on animal welfare labeling and establishing a Community Reference Centre for Animal Protection and Welfare, DG SANCO, Brussels.

4. European Commission (2012): Communication from the Commission to the European Parliament, the Council and the European Economic and Social Committee on the European Union Strategy for the Protection and Welfare of Animals 2012-2015, Brussels.

5. Filipovic, J., Stojanovic, Z. (2013): Consumer Perception and Use of Products with Health Claims in Western Balkan Countries, In: (eds. Smutka, L.,Zagata, L.) Agrarian perspectives XXII - Development trends in agribusiness, Prague, Sept 2013., Faculty of Economics and Management, Czech University of Life Sciences, Prague, pp. 199-211.

6. Grimsrud, K.M., Nielsen, H.M., Navrud, S., Olesen, I. (2013): Households'willingnessto-pay for improved fish welfare in breeding programs for farmed Atlantic salmon, Aquaculture, Vol. 372-375, pp. 19-27.

7. Harper, G., Henson, S. (2001): Consumer Concerns about Animal Welfare and the Impact on Food Choice, EU FAIR Final Report, no. CT98-3678, Reading, UK.

8. Ingenbleek, P., Harvey, D., Ilieski, V., Immink, V. M., De Roest, K., Schmid, O. (2013): The European market for animal-friendly products in a societal context, Animals, Vol. 3, No. 3, pp. 808-829.

9. Kehlbacher, A., Bennett, R., Balcombe, K. (2012): Measuring the consumer benefits of improving farm animal welfare to inform welfare labelling, Food Policy, Vol. 37, No. 6, pp. 627-633.

10.Krystallis, A., Grunert, K., Barcellos, M., Perrea, T., Verbeke, W. (2012): Consumer attitudes towards sustainability aspects of food production: Insights from three continents, Journal of Marketing Management, Vol. 28, No. 3-4, pp. 334-372.

11. Lagerkvist, C. J., Hess, S. (2011): A meta-analysis of consumer willingness to pay for farm animal welfare, European Review of Agricultural Economics, Vol. 38, No. 1, pp. 55-78.

12. Matsuoka, A., Sorenson, J. (2013): Human Consequences of Animal Exploitation: Needs for Redefining Social Welfare, Journal of Sociology \& Social Welfare, Vol. XL, No. 4, pp. 7-32.

13. Napolitano, F., Pacelli, C., Girolami, A., Braghieri, A. (2008): Effect of information about animal welfare on consumer willingness to pay for yogurt, Journal of dairy science, Vol. 91, No. 3, pp. 910-917.

14. Nocella, G., Hubbard, L., Scarpa, R. (2010): Farm Animal Welfare, Consumer Willingness to Pay, and Trust: Results of a Cross-National Survey, Applied Economic Perspectives and Policy, Vol. 32, No. 2, pp. 275-297.

15.Pelsmacker, P. D., Janssens, W., Sterckx, E., Mielants, C. (2006): Fair-trade beliefs, attitudes and buying behaviour of Belgian consumers, International Journal of Non-profit and Volunary Sector Marketing, Vol. 11, No. 2, pp. 125-138.

16. Redmond, E., Griffith, C. (2003): A comparison and evaluation of research methods used in consumer food safety studies, International Journal of Consumer Studies, Vol. 27, No. 
1, pp.17-33

17. Schröder, M. J., McEachern, M. G. (2004): Consumer value conflicts surrounding ethical food purchase decisions: a focus on animal welfare, International Journal of Consumer Studies, Vol. 28, No. 2, pp. 168-177.

18. Shih-Jui, T., Jenner, C. T., Meng-Chu, L. (2015): Life course, diet-related identity and consumer choice of organic food in Taiwan, British Food Journal, Vol. 117, No. 2, pp. 688-704.

19. Steptoe, A., Pollard, T. M., Wardle, J. (1995): Development of a Measure of the Motives Underlying the Selection of Food: the Food Choice Questionnaire, Appetite, Vol. 25, pp. 267-284.

20. Stojanović, Ž., Gligorijević, M., Ognjanov, G., Veljković, S., Mitić, S., Filipović, J., Ilić, J., Burazerović, J., Burazerović, E. (2014a): Stavovi potrošača u Srbiji o dobrobiti životinja: Istraživanje stavova potrošača u Srbiji o uticaju standarda dobrobiti farmskih životinja na kvalitet $i$ bezbednost hrane, Organizacija za poštovanje i brigu o životinjama - ORCA, Beograd.

21. Stojanović, Ž.,Veljković, S., Ognjanov, G. (2014b): Znanje i percepcija potrošača u Srbiji o dobrobiti farmskih životinja - primer primene evropskih politika, In: (ed. Cerović, B.) Uloga države u novom modelu rasta privrede Srbije, Centar za izdavačku delatnost, Ekonomski fakultet, Beograd, pp. 157-173.

22. Stojanović, Ž., Gligorijević, M., Ognjanov, G., Veljković, S., Mitić, S., Filipović, J. (2014c): Consumer attitudes toward farm animal welfare standards and their influence on food quality and safety, survey research, internal documentation (questionnaires), Faculty of Economics, Belgrade.

23. Taylor, N., Signal, T. D. (2009): Willingness to pay: Australian consumers and "on the farm " welfare, Journal of Applied Animal Welfare Science, Vol. 12, No. 4, pp. 345-359.

24. The Food Safety Low, Official Gazette of the Republic of Serbia, no. 41/2009.

25. The Law on Animal Welfare, Official Gazette of the Republic of Serbia, no. 41/2009.

26. Theuvsen, L., Essmann, S., Brand-Saßen, H. (2006): Does more animal welfare in Turkey husbandry pay off? Empirical evidence from Germany, Unternehmen im Agrarbereich vor neuen Herausforderungen: 45. Jahrestagung der Gesellschaft für Wirtschafts- und Sozialwissenschaften des Landbaues, pp. 339-348.

27. Toma, L., McVittie, A., Hubbard, C., Stott, A. (2011): A Structural Equation Model of the Factors Influencing British Consumers'Behaviour toward Animal Welfare, Journal of Food Products Marketing. Vol. 17, Issue 2/3, pp. 261-278.

28. Toma, L., Stott, A.W., Revoredo Giha, C., Kupiec Teahan, B. (2012): Consumers and animal welfare. A comparison between European Union countries, Appetite, Vol. 58, No. 2, pp. 597-607.

29. Vecchio, R., Annunziata, A. (2012): Italian consumer awareness of layer hens'welfare standards: a cluster analysis, International Journal of Consumer Studies, Vol. 36, No. 6, pp. 647-655.

30.Zakić, Z., Stojanović, Ž. (2008): Ekonomika agrara, Ekonomski fakultet Beograd. 


\title{
STAVOVI PREMA DOBROBITI FARMSKIH ŽIVOTINJA I KUPOVNE NAMERE POTROŠAČA - PRIMER SRBIJE
}

\author{
Saša Veljkovičc ${ }^{4}$ Žaklina Stojanovićc ${ }^{5}$ Jelena Filipovićc
}

\begin{abstract}
Sažetak
Cilj ovog istraživanja je da se ispita percepcija potrošača u pogledu prehrambenih proizvoda povezanih sa dobrobiti farmskih životinja; kao i da se utvrdi faktori koji utiču na to da potrošači plate premijumsku cenu za navedene proizvode. Četiri segmenta potrošača su identifikovana, na bazi njihovih stavova prema dobrobiti životinja $i$ njihove karakteristike su detaljno objašnjene. Istraživanje je sprovedeno u Beogradu na 198 ispitanika, tehnikom ličnog intervjua. Za analizu rezultata korišćeni su metodi regresione i klaster analize. Rezultati pokazuju da prehrambeni sektor treba da uloži više napora u informisanje i edukaciju potrošača o važnosti dobrobiti životinja, kao i da postoji značajan tržišni potencijal za uvođenje oznake za proizvode koji su proizvedeni u skladu sa standardima za dobrobit životinja. Implikacije za donosioce zakona takođe su predložene i razmatrane u radu.
\end{abstract}

Ključne reči: dobrobit životinja, potrošači, segmentacija tržišta, hrana, Srbija.

4 Prof. dr Saša Veljković, Vanredni profesor, Ekonomski fakultet, Univerzitet u Beogradu, Kamenička 6, 11000 Beograd, Telefon: +381 113021 125, E-mejl: veljkos@ekof.bg.ac.rs

5 Prof. dr Žaklina Stojanović, Redovni profesor, Ekonomski fakultet, Univerzitet u Beogradu, Kamenička 6, 11000 Beograd, Telefon: +381 113021 162, E-mejl: zaklina@ekof.bg.ac.rs

6 Doc. dr Jelena Filipović, Ekonomski fakultet, Univerzitet u Beogradu, Kamenička 6, 11000 Beograd, Telefon: +381 113021 023, E-mejl: jfilipovic@ekof.bg.ac.rs 